\title{
Method Development and Validation of UV Spectro Photometric Method for Determination of Diazepam in its Pure and Pharmaceutical Dosage Form
}

\author{
P. Venkates wara Rao ${ }^{1}$, K.Harini ${ }^{1}$, G. Venkat Chaithanya ${ }^{1}$, N. Sai Reddy ${ }^{1}$, A. Sireesha*1 \\ ${ }^{1}$ Department of Pharmaceutical Analysis, St. Mary's Group of Institutions Guntur, Chebrolu (V\&M), Guntur, \\ Andhra Pradesh, India.
}

*Corresponding Author: A. Sireesha, Department of Pharmaceutical Analysis, St. Mary's Group of Institutions Guntur, Chebrolu (V\&M), Guntur, Andhra Pradesh, India.

\begin{abstract}
An UV spectrophotometric method for the quantitative determination of Diazepam in tablet was developed in present work. The Linearity, Intraday precision, Interday Precision, Ruggedness, limit of detection and limit of quantitation were studied according to International Conference on Harmonization guidelines. UV spectroscopic determination was carried out at an absorption maximum of $266.5 \mathrm{~nm}$ using methanol as solvent. The method was found to be linear and obeys beers law in the concentration range 2-20 $\mu \mathrm{g} / \mathrm{ml}$ with a correlation coefficient 0.999. The developed method was validated as per ICH guidelines and was found to be accurate and precise. Thus the proposed method can be successfully applied for the estimation of Diazepam in pure and tablet dosage form.
\end{abstract}

Keywords: Diazepam, Linearity, Intraday precision, Interday Precision and Ruggedness

\section{INTRODUCTION}

Diazepam (DZP), most commonly known by its trade name Valium, is a benzodiazepine and chemically it is 7-chloro-1, 3-dihydro-1-methyl-5- phenyl-1, 4- benzodiazepin-2-one. The structural formula of Diazepam with molecular formula $\mathrm{C} 16 \mathrm{H} 13 \mathrm{CIN} 2 \mathrm{O}$, is shown in Figure 1. It is commonly used to treat a wide range of conditions including anxiety, panic attacks, insomnia, seizures (including status epilepticus), muscle spasms (such as in tetanus cases), restless legs syndrome, alcohol withdrawal syndrome, benzodiazepine withdrawal syndrome, opioid withdrawal syndrome, and Ménière's disease. However, it is a potent sedative- hypnotic, and is one of the most prescribed drugs in the world. It is also one of the top five most abused benzodiazepines, and misuse can lead to both psychological dependence and/or physical addiction1.

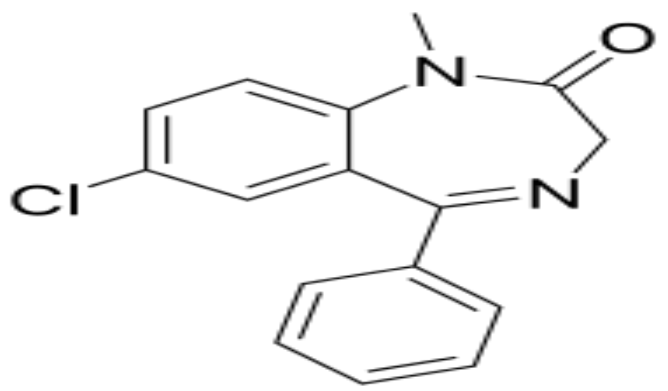

Fig1. Structure of Diazepam

Because of the therapeutic importance of DZP, many methods have been developed for its determination in pharmaceutical dosage forms and/or biological fluids. Literature survey reveals that various methods like Spectrophotometry2-4, gas liquid chromatography5, fluorimetry6, first derivative spectroscopy7, capillary electrophoresis 8 and HPLC9-10 are reported for the estimation of Diazepam in single dosage form. However, most of these methods are tedious and involve expensive and sophisticated experimental set up which many ordinary quality control laboratories cannot afford. Spectrophotometry occurs in the forefront of the most sensitive and widely used analytical techniques. 
In recent years, it has found wide applications for the determination of many important drugs11-14. Various spectrophotometric methods have been used for determination of DZP. The present investigation was carried out in the view of establishing a simple, rapid, accurate, economic, precise and robust UV method for estimation Diazepam in bulk and tablet dosage form using water as the solvent.

\section{MATERials}

\subsection{Instrument}

LABINDIA UV -3200 double beam uv-visible spectrophotometer with pair of $10 \mathrm{~mm}$ matched quartz cells.

\subsection{Chemicals and Reagents}

All the reagents and solvents were of analytical grade high purity deionized water. Loratidine was obtained as a gift from Spectrum Labs, Hyderabad. All other chemicals used were of analytical grade.

\section{METHODS}

\subsection{Pre paration of standard solution}

\subsubsection{Preparation of Standard Stock Solution}

Standard stock solution of Diazepam drug was prepared by accurately weighing about $10 \mathrm{mg}$ of each drug in $10 \mathrm{ml}$ volumetric flask. The drugs were dissolved with $5 \mathrm{ml}$ of methanol, and sonicated to dissolve it completely and made up to the mark with the same solvent; results $1000 \mu \mathrm{g} / \mathrm{ml}$ solution was obtained.

\subsubsection{Preparation of Formulation Sample}

Diazepam tablets (Placidox - 10mg) were purchased from local pharmacy. Ten tablets were weighed and average weighed was calculated. The tablet powder equivalent to $10 \mathrm{mg}$ of Diazepam was transferred in to a $10 \mathrm{ml}$. $3 \mathrm{~mL}$ of methanol was added and sonicated for complete solubility. The volume was made up to the mark with methanol. From this sample stock solution of $1000 \mu \mathrm{g} / \mathrm{ml}$ concentration final concentration $10 \mu \mathrm{g} / \mathrm{ml}$ was prepared.

\subsection{Measurement of Absorbance and Calibration Curve}

The absorbance of the solutions containing DIAZEPAM at $100 \mu \mathrm{g} / \mathrm{mL}$ was determined in the UV range $200-400 \mathrm{~nm}$ using an appropriate blank. The $\lambda$ max was found to be $245.5 \mathrm{~nm}$. At this wavelength, calibration curve was drawn by plotting graph between absorbance and concentrations.

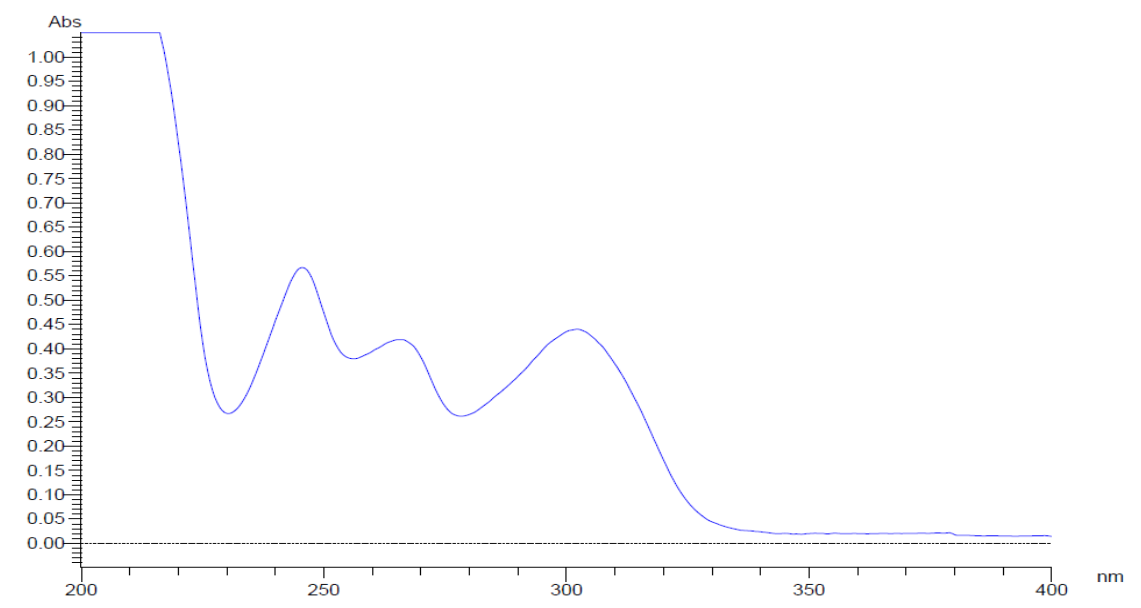

Fig2. Determination of Wavelength of Loratadine

\section{Method Validation}

\subsection{Linearity}

The linearity of the method was demonstrated over the concentration range of $2-12 \mu \mathrm{g} / \mathrm{mL}$. A Series of dilutions were made by using the stock solution. From the stock solution 0.2,0.4,0.6,0.8,1.0 and 1.2 
Method De velopment and Validation of UV S pectro Photometric Method for Determination of Diazepam in its Pure and Pharmaceutical Dosage Form

$\mathrm{mL}$ were pipette out into a $10 \mathrm{~mL}$ volumetric flasks and diluted with methanol and finally make up to the volume with methanol. The resulting solutions were labelled as $2,4,6,8,10$ and $12 \mu \mathrm{g} / \mathrm{mL}$. The linearity was calculated by the least square regression method

Table1. Results of Linearity

\begin{tabular}{|c|c|c|}
\hline S. No & Concentration in $\boldsymbol{\mu g} / \mathbf{m l}$ & Absorbance \\
\hline 1 & 2 & 0.234 \\
\hline 2 & 4 & 0.381 \\
\hline 3 & 6 & 0.536 \\
\hline 4 & 8 & 0.694 \\
\hline 5 & 10 & 0.835 \\
\hline 6 & 12 & 0.986 \\
\hline \multicolumn{2}{|c|}{ CorrelationCoefficient:0.9994 } \\
\hline
\end{tabular}

\section{Diazepam - Standard}

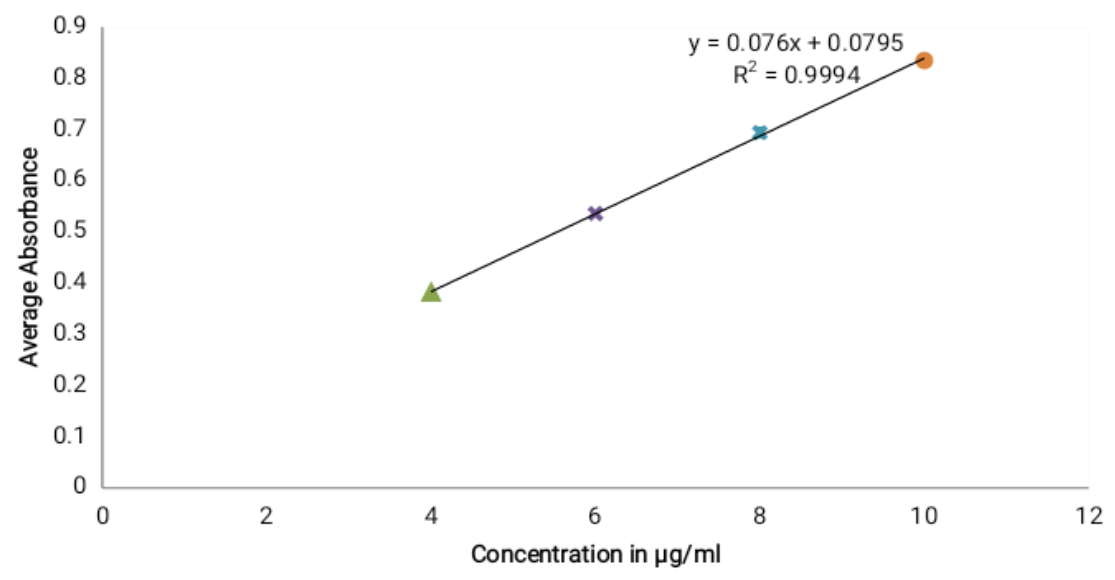

Fig3. Calibration Curve of Diazepam

\subsection{Precision}

The precision of the assay was determined by repeatability (intraday) and intermediate precision (inter-day) and reported as percent RSD. For this $6 \mu \mathrm{g} / \mathrm{mL}$ concentration solution was measured six times in day and same was measured in next day also. The percent RSD was calculated. Table2. Results Precision

Table2. Results of Intraday precision

\begin{tabular}{|c|c|c|}
\hline S.NO & Concentration in $\boldsymbol{\mu g} / \mathbf{m l}$ & Absorbance \\
\hline 1 & 6 & 0.536 \\
\hline 2 & 6 & 0.531 \\
\hline 3 & 6 & 0.533 \\
\hline 4 & 6 & 0.532 \\
\hline 5 & 6 & 0.532 \\
\hline 6 & 6 & 0.534 \\
\hline
\end{tabular}

Table3. Results of Interday Precision

\begin{tabular}{|c|c|c|}
\hline S. No & Concentration in $\mathbf{~ g} / \mathbf{m l}$ & Absorbance \\
\hline 1 & 6 & 0.538 \\
\hline 2 & 6 & 0.539 \\
\hline 3 & 6 & 0.537 \\
\hline 4 & 6 & 0.538 \\
\hline 5 & 6 & 0.535 \\
\hline 6 & 6 & 0.539 \\
\hline & RSD:0.280 & \\
\hline
\end{tabular}


Method De velopment and Validation of UV S pectro Photometric Method for Determination of Diazepam in its Pure and Pharmaceutical Dosage Form

\section{Accuracy (Recovery)}

The accuracy of the method was evaluated through standard addition method. In this, known amount of standard diazepam $4 \mu \mathrm{g} / \mathrm{mL}$ was added in pre-analyzed sample for 2,4 and $6 \mu \mathrm{g} / \mathrm{mL}$ in triplicate.

Table4. Results of Accuracy

\begin{tabular}{|c|c|c|c|c|c|c|}
\hline S No & Spiked Level & Target $(\mu \mathrm{g} / \mathrm{ml})$ & Spiked $(\mu \mathrm{g} / \mathrm{ml})$ & Final $(\mu \mathrm{g} / \mathrm{ml})$ & Amount found $(\mu \mathrm{g} / \mathrm{ml})$ & \% Recovered \\
\hline 1 & \multirow{3}{*}{$50 \%$} & 4 & 2 & 6 & 5.91 & 98.50 \\
\hline 2 & & 4 & 2 & 6 & 5.93 & 98.83 \\
\hline 3 & & 4 & 2 & 6 & 5.89 & 98.17 \\
\hline 4 & \multirow{3}{*}{$100 \%$} & 4 & 4 & 8 & 7.98 & 99.75 \\
\hline 5 & & 4 & 4 & 8 & 7.91 & 98.875 \\
\hline 6 & & 4 & 4 & 8 & 7.86 & 98.25 \\
\hline 7 & \multirow{3}{*}{$150 \%$} & 4 & 6 & 10 & 9.89 & 98.90 \\
\hline 8 & & 4 & 6 & 10 & 9.93 & 99.30 \\
\hline 9 & & 4 & 6 & 10 & 9.91 & 99.10 \\
\hline
\end{tabular}

\subsection{Limit of Detection (LOD)}

The parameter LOD was determined on the basis of intercept and slope of the regression equation. The LOD for this method was found to be $0.07 \mu \mathrm{g} / \mathrm{mL}$.

\subsection{Limit of Quantification (LOQ)}

The parameter LOQ was determined on the basis of intercept and slope of the regression equation. The LOQ for this method was found to be $0.25 \mu \mathrm{g} / \mathrm{mL}$.

Table5. $L O D \& L O Q$

\begin{tabular}{|c|c|}
\hline LOD & $0.07 \mu \mathrm{g} / \mathrm{ml}$ \\
\hline LOQ & $0.25 \mu \mathrm{g} / \mathrm{ml}$ \\
\hline
\end{tabular}

\subsection{Ruggedness}

Table6. Results of Ruggedness

\begin{tabular}{|c|c|c|}
\hline S.NO & Concentration in $\boldsymbol{\mu g} / \mathbf{m l}$ & Absorbance \\
\hline 1 & 6 & 0.539 \\
\hline 2 & 6 & 0.542 \\
\hline 3 & 6 & 0.542 \\
\hline 4 & 6 & 0.541 \\
\hline 5 & 6 & 0.546 \\
\hline 6 & 6 & 0.549 \\
\hline & \multicolumn{2}{|c|}{ RSD:0.673 } \\
\hline
\end{tabular}

\section{Validation Parameters}

Table7. Validation Parameters

\begin{tabular}{|c|c|}
\hline Parameter & Result \\
\hline Absorption Maxima $(\mathrm{nm})$ & $245.5 \mathrm{~nm}$ \\
\hline Linearity Range $(\mu \mathrm{g} / \mathrm{mL})$ & $2-12 \mu \mathrm{g} / \mathrm{Ml}$ \\
\hline Standard Regression Equation & $\mathrm{y}=0.076 \mathrm{x}+0.0795$ \\
\hline Correlation Coefficient $(\mathrm{r} 2)$ & 0.9994 \\
\hline Accuracy $(\%$ Recovery $\pm \mathrm{Sd})$ & $98.85 \pm 0.636$ \\
\hline LOD $(\mu \mathrm{g} / \mathrm{mL})$ & $0.07 \mu \mathrm{g} / \mathrm{Ml}$ \\
\hline $\mathrm{LOQ}(\mu \mathrm{g} / \mathrm{mL})$ & $0.25 \mu \mathrm{g} / \mathrm{mL}$ \\
\hline
\end{tabular}

\section{Determination of Diazepam In TABLETS}

Diazepam tablets (valium10mg) were purchased from local pharmacy. Ten tablets were weighed and average weighed was calculated. The tablet powder equivalent to $10 \mathrm{mg}$ of Diazepam was transferred in to a $10 \mathrm{ml}$. $3 \mathrm{Ml}$ of methanol was added and sonicated for complete solubility. The volume was made up to the mark with methanol. From this sample stock solution of $1000 \mu \mathrm{g} / \mathrm{ml}$ concentration final concentration $10 \mu \mathrm{g} / \mathrm{ml}$ was prepared. 
Method De velopment and Validation of UV S pectro Photometric Method for Determination of Diazepam in its Pure and Pharmaceutical Dosage Form

\subsection{Validation}

Table8. Assay of Diazepam in Tablets

\begin{tabular}{|c|c|c|c|c|c|c|}
\hline S. No & Brand name & vailable form & Label claim & Concentration & Amount found & \% Assay \\
\hline 1 & Valium & Tablet & $10 \mathrm{mg}$ & $6 \mu \mathrm{g} / \mathrm{ml}$ & $5.92 \mu \mathrm{g} / \mathrm{ml}$ & 98.67 \\
\hline
\end{tabular}

\section{DIS CUSSION}

For optimize the method by UV for diazepam, different solvents were tested such as Water and methanol. Due to greater solubility and reproducible readings of maximum absorbance, methanol was taken for further work. Standard diazepam $(10 \mathrm{mg})$ was accurately weighed and transferred to $10 \mathrm{~mL}$ volumetric flask. It was dissolved properly and diluted up to the mark with methanol to obtain a concentration of $1000 \mu \mathrm{g} / \mathrm{mL}$. By using this solution different concentrations of $2,4,6,8,10,12 \mu \mathrm{g} / \mathrm{mL}$ were prepared and calibration curve was plotted by plotting graph between absorbance and concentration (Fig.2). The results of linearity are presented in table 1. The data was statistically validated by means of least square regression method. The detection and quantization limits as LOD $(\mathrm{k}=3.3)$ and LOQ $(\mathrm{k}=10)$ were calculated and these were found to be $0.1017 \mu \mathrm{g} / \mathrm{mL}$ and 0.3079 $\mu \mathrm{g} / \mathrm{mL}$ respectively. The precision (measurements of intraday and interday) results showed good reproducibility with percent relative standard deviation (\% RSD) is below 2.0. This indicates the method was précised. The accuracy of the method was performed by standard addition method. The average recovery was found to be $98.5 \%, 98.95 \%$ and $99.1 \%$ respectively and the accuracy results showed good recovery with percent relative standard deviation (\% RSD) is below 2.0. This indicates accuracy of proposed method was also applied for the assay of diazepam in tablets. The results as tabulated in Table 4 . The results obtained were satisfactory and good agreement as per the ICH guidelines.

\section{CONCLUSion}

Although various methods have been developed for the estimation of Diazepam individually and in combinations with other drugs, no method has been published till now with a selected solvent. The present work done on this a simple, precise and accurate method by UV spectrophotometric method. The proposed methods can be successfully applied for diazepam assay in tablet dosage forms without any interference of excipients in quality control. Analysis of the tablets by this method were reproducible, reliable and in good agreement with $\mathrm{ICH}$ guide line The linearity and absorbance was determined, the concentration of Diazepam were then determined by comparing the absorbance sample with that of standard of Diazepam can be identified by their lambda maximum being 245.5 $\mathrm{nm}$. The results obtained from UV method were reproducible and encouraging.

\section{ACKNOWLEDGEMENT}

The authors are Thankful to Rev Dr. K. V. K. Rao and Dr. P. Venkateswara Rao, principal for providing the facilities to carry out this research work in St. Mary's Group of Institutions Guntur.

\section{REFERENCES}

[1] British Pharmacopoeia, the British Pharmacopoeia Secretariat of the Medicines and Healthcare products Regulatory Agency, UK, 2009.

[2] El-Hawary WF, Issa YM, Talat A, Spectrophotometric Determination of Diazepam in Pure Form, Tablets and Ampoules. International Journal of Biomedical Science 2007, 3, pp. 50-55.

[3] Dastidar D G and Biswanath S, A Comparative Study of UV-Spectrophotometry and First-Order Derivative UV-Spectrophotometry Methods for the Estimation of Diazepam in Presence of Tween-20 and Propylene Glycol, 2009, 10, pp. 1396.

[4] Manes J, Civera J, Font G, Bosch F, Spectrophotometric determination of benzodiazepines in pharmaceuticals by ion pairing, Cienc. Ind. Farm 1987, 6, pp 333-338.

[5] Arthur J, De silva F, Morton A, Stefanovic V, Kaplan J. The Liquid Chromatography of Some Benzodiazepines. Hoffmann-la Roche Inc., 1964, 36, pp. 2099.

[6] Salem AA, Barsoum BN, Izake EL. Spectrophotometric and fluorimetric determination of diazepam, bromazepam and clonazepam in pharmaceutical and urine samples. Spectrochim Acta A Mol Biomol Spectrosc., 2004, 60 (4), pp. 771-780. 
[7] Mannucci C, Bertini J, Cocchini A, Perico A, Salvagnini F, Triolo A. Simultaneous determination of otiloniu m bromide and diazepam by first derivative spectroscopy. J Pharm Sci., 1992, 81 (12), pp. 11751177.

[8] Furlanetto S, Orlandini S, Massolini G, Faucci MT, La Porta E, Pin zauti S. Optimis ation and validation of a capillary electrophoresis method for the simultaneous determination of diazepam and otiloniu m bromide. Analyst, 2001, 126 (10), pp 1700-1706.

[9] Samia M, El-Gizawy M. Simu ltaneous Determination of Diazepam, Oxazepam and Temazepam in Spiked Urine by HPLC. Analytical Letters, 2000; 33 (4), pp. 629-638.

[10] Moore C, Coulter C, Crompton K, Determination of Benzodiazepines in Urine and Blood Using Rapid Resolution Liquid Chromatography/Triple Quadrupole Mass Spectrometry. Agilent Technologies, Immunalysis Corporation, Pomona, CA, 2007, pp. 5989-7201.

[11] Gehad G M, Nour El-Dien F A, Khalil S M, Nehad A M, Spectrophotometric determination of trazodone, amineptine and a mitriptyline hydrochlorides through ion-pair formation with molybdenum and thiocyanate Spectrochimica Acta Part A, 2006, 65, pp. 1221-1226

[12] Kaura A, Gupta V, Roy G S, Kaura M, Spectrophotometric determination of chlorpheniramine maleate and phenylpropanolamine hydrochloride in dosage forms, International Current Pharmaceutical Journal, 2013, 2 (5), pp. 97-100

[13] Naveed, S, Simple UV Spectrophotometric Assay of Atorvastatin API Formulation and Their Comparative Study. Global Journal of Medical Research, 2014, 14, pp. 35-38.

[14] Akhoundi-Khalafi A M, Masoud R S, New Technique for Quantitative Determination of Dexamethasone in Pharmaceutical and Biological Samples Using Kinetic Spectrophotometric Method, International Journal of Analytical Chemistry, 2015, 2015, pp. 1-6.

Citation A. Sireesha, et al., "Method Development and Validation of UV Spectro Photometric Method for Determination of Diazepam in its Pure and Pharmaceutical Dosage Form", ARC Journal of Pharmaceutical Sciences(AJPS), vol. 4, no. 2, p. 18-23, 2018.http://dx.doi.org/10.20431/2455-1538.0402003

Copyright: (C) 2018 Authors. This is an open-access article distributed under the terms of the Creative Commons Attribution License, which permits unrestricted use, distribution, and reproduction in any medium, provided the original author and source are credited 